\title{
DE KAMERS VAN KOOPHANDEL ALS ADVISEERENDE COLLEGES,
}

Wee den wolf die in een kwaad gerucht staat.

Achttien jaar zijn verloopen, sinds in dit Tijdschrift de Kamers van Koophandel en Fabrielen in verhandelingen van de heeren W. J. Roelfsema Hz. en Abram Muller besproken zijn geworden. Na dien tijd kwam het onderwerp hier niet aan de orde.

Naar aanleiding van de nu aanhangige poging tot reorganisatie vergunne mij de redactie enkele opmerkingen te maken over de beteekenis en de rol van deze wettelijke vertegenwoordigers der industrie en van den handel.

Een probleem, een moeilijkheid, een kwaal of kwaad vraagt om een oplossing; en terwijl anderen meer beroegden het geneesmiadel definitief zullen aanwijzen, zij hier de diagnose gesteld, en zoo objectief mogelijk de zaak uiteengezet, voor een deel met gebruikmaking van eigen ervaring als secretaris.

Toen ik mij te Hilversum destijds gevestigd had, werd mijn aandacht getrokken door het feit, dat enkele gemeentelijke belangen op min gelukkige wijze voorgedragen werden; en blijkbaar den Gemeenteraad niet de zakenliemnis ten dienste stond die bij onderhandelingen met andere corporaties noodig is, willen moeilijke zaken tot een goed einde komen; zulke zaken waren: de stichting ran een groentenveiling; de vaartverbetering op Amsterdam; de verbinding van het deel der kom dat achter de lijn der Hollandsche Spoor ligt met het overige en meer zulke zuiver lokale belanjen. Daarbij voegden zich later de telefoon-centrale voor het Gooi, de tramverbindingen en de electriciteitsvoorziening, plaatselijke en streekbelangen, die ook jaren lang sleepten.

Dat de vertegenwoordigers van het algemeen belang, Burgemeesters en Wethouders, raadscommissies, niet fortuinlijk waren bij de onderhandelingen, stond vast; en toentertijd schenen daar de personen te ontbreken die de ervaring van mannen van zaken mee konden brengen, 
die noodig is om aan de business-men, de wederpartij, het gevoel bij te brengen, van parturur te hebben.

Was er dan geen Kamer van Koophandel, om v a $n$ het standpunt van het algemeen belang é $n$ met $z$ ake $n k e n n i s$ den Raad te steunen door zijn adviezen?? Neen. Ofschoon belangrijke industrieplaats, en ofschoon de ligiging het tot een verkeerscentrum maakt, had Hilversum geen kamer.

In April 1913 werd het initiatief tot oprichting genomen; en in April 1914 had de installatie der door den Raad op het rekest van een 30-tal personen toegestane en door de Regeering ingestelde Kamer met 9 leden plaats. Ik had de eer tot haren eersten secretaris te worden gekozen; een functie die ik met bijzonder veel genoegen, zij het ook slechts borten tijd -. tot mijn vertrek naar hier - heb bekleed.

Uit dezen kleinen aanloop vernieuwe de lezer de allicht sluimerende herinnering aan de wettelijke bepalingen omtrent de rol en de wijze van tot stand komen van Kamers van Koophandel en Fabrieken; en zal wel even het K. B. van 4 Mei 1896 willen opslaan, om over de wijze van verkiezing der leden en de geldmiddelen zich weder op de hoogte te stellen.

Van de meergenoemde opstellen in dit tijdschrift was een poging tot reorganisatie de aanleiding, die in het jaar 1898 een deel der Kamers in beweging bracht. Die reorganisatieplannen beoogden: regeling door de wet in plaats yan regeling bij Koninklijk Besluit; verbetering in de methode van adviseeren van de Regeering; bestuursbevoegdheden naast den zuiver adviseerenden werkkring in te stellen.

Deze beweging liep clood. De oorzaak van dit mislukken lag in het uitblijven zoowel van parlementair initiatief als van Regeerings belangstelling; maar ook ging de goed bedoelde poging niet met een geheel juist inzicht gepaard.

Te weinig verwachtten de adresseerende Kamers van handen uit de mouwen steken, te veel van den Nederlandschen wetgever.

In de ter gelegenheid van de Eerste Jaarbeurs op 6 Maart te Utrecht belegde vergadering van afgevaardigden der gezamenlijke Kamers ran Koophandel had ik de eer, een inleiding over het onderwerp der reorganisatie te geven.

Ik beleed mij voorstander van het behoud van het adviseerend karakter der colleges, en van een regeling bij 
Koninklijk Besluit. Maar ik ging verder dan de reorganisatieplannen van 1898, in zooverre ik scherpe, onvoorwaardelijke, onafhankelijkheid van de Kamer van Koophandel van den Gemeenteraad in alle opzichten noodig acint, als een onontbeerlijk vereisohte, om de taak als adviseerende colleges behoorlijk te vervullen.

De adresbeweging van 1898 had dit groote gebrek in den bestaanden toestand, vreemd genoeg, over het hoofd gezien!

De tegenwoordige afhankelijkheid van de Gemeenteraden doet aan het gezag der Kamers groote afbreuk; $z \mathrm{ij}$ onthoudt hun de geldmiddelen die noodig zijn; zij is oorzaak van de overheerschende stemming - bij hoog en bij laag voorkomend - van , die Kamers van Koophandel, wat zullen die toch.? ? "

Die stemming was aan de leden zelf van onze Hilversumsche Kamer niet vreemd. Wee den wolf die in een kwaad gerucht staat! Maar allengs werd dat anders, toen in enkele der genoemde lokale belangen de Kamer met degelijke adviezen voor den dag kwam.

De financiëele afhankelijkheid leidde te Hilversum reeds in het eerste jaar tot een conflict, dat door de in. geroepen tusschenkomst van Gedeputeerde Staten onmiddellijk in het voordeel der Kamer beslist werd!

In dezen geest sprak ik ter vergadering te Utrecht. Mijn praeadvies zoowel als de inleiding lokten eenige gewaardeerde opmerkingen uit, tot... als een plotseling losbarstend kanonvuur geheel andere klanken werden vernomen. De heer D. W. Stork, lid der Eerste Kamer, die als voorzitter der Hengelosche Kamer de vergadering kwam bijwonen, nam het woord en vroeg, tegenover mijn standpunt stelling nemend, of de Kamers niet veel liever moesten aansturen op een geheele, fundamenteele, wijziging in de vertegenwoordiging van handel en nijverheid, een wijziging die mogelijk zelfs de opheffing der Kamers zelve zou inhouden of meebrengen. Met aplomb voorgedragen, sloeg dat woord in! De discussies werden niet voortgezet; maar met overweldigende meerderheid werd besloten, het denkbeeld van den heer Stork over te nemen.

Thuis gekomen, zullen de afgevaardigden wellicht betreurd hebben, dat men niet verder is gekomen dan : een opdracht aan de leidiers der vergadering, om het samenstellen van een commissie te bevorderen die tot taak zal hebben... de vertegenwoordiging van den $\mathrm{Ne}$ derlandschen Handel, van de Nederlandsche Nijverheid, van scheepvaart, geldwezen en middenstand $a b$ ovo te herzien. 
Menigeen zal allicht meer practische, resultaten van de vergadering hebben verwacht.

Menigeen zal het advies van den heer Stork zeer hebben verrast.

Veryat deze, dat de Kamers ran Koophandel de lichamen niet zijn, om een reorganisatie van zijn standpunt te bezien, hetwelk, zooals hij zelf zeide, zelfs een o ph e f f i ng der Kamers niet uitgesloten acht?!

Hoe is de instemming te verklaren die de heer Stork verwierf? Er was iets van een hoerah-stemming in de vergadering, als gevolg van het even te voren behanclelde protest tegen het negeeren der Kamers bij de crisismaatregelen! In die eenigszins opgewonden stemming en, als iedereen in dit tijdsgewicht, vervuld van het besef, dat grootsche bewegingen nu succes kunnen hebben, schonk de vergadering aan de improvisatie van den heer Stork hare bewondering.

Maar omdat de tijd dringt; en omdat de lessen der ervaring leeren, dat de bestudeering der kwestie op zóó breeden grond tot niets leidt, daarom betreur ik dien afloop. Komt de commissie tot stand, dan zal haar advies vermoedelijk een langen tijd van voorbereiding vergen. Indien bijvoorbeeld meervoudig kiesrecht wordit overwogen; of indien de kwestie van splitsing der belangen van groot-industrie en klein-bedrijf, van groothandel en middenstand wordt opgeworpen, dan zal de commissie een reusachtige taak hebben en ten slotte toch tot het beginsel van ons tegenwoordig stelsel terugkeeren.

Eén ding toch staat vast. De in 1851 ingestelde, "Kamers van Koophandel en Fabrieken" vertegenwoordigen den handel en de nijverheid als organen van het $S t$ a t s g e $z$ ag. Dit houdt in, dat $z i j$ belangen van handel en nijverheid niet mogen vereenzelvigen met, de belangen van de handelaren en de nijveren"!

De Statstaak, dus ook hunne taak, is ten opzichte van steun a n handel en nijverheid beperkt tot die gevalle n, wa a rinonbetwistbaar vaststaat, dat ook het algemeen belang, dus met $n$ ame het belang der werknemers en indirect ook de belangen der consumenten, met de beoogdie maatregelen tot steun gebaat $z$ ulle $n z$ ij $n$. Waar dit vaststaat, daar twijfel ik of een opzet gevonden kan worden geheel verschillend: van dien van den genialen Thorbecke.

Zeker er zijn andere stelsels. In Engeland zijn de Chambers of Commerce zuiver privaat-rechtelijke vereenigingen. Maar waar hier te lande de public spirit zich 
toch al zoo veel beschroomder uit dan ginds, is het dan geraden, het hier met zulke vereenigingen naar Britsch model te probeeren?

Ooki bevreemdde het menigeen, dat de heer Stork de zaak commissioriaal liet maken; en niet met een uitgewerkt plan voor den dag kwam! Hij, lid van het parlement èn voorzitter van eene Kamer tevens, was daarvoor de man geweest.

Stellen wij nu nog eens de verschillende oorzaken van de verzwakking der Kamers vast.

De door Thorbecke ontworpen regeling werd, wat het kiesrecht betreft, in 1896 veel slechter gemaakt dan zij was.

Behalve de wijziging van dat jaar heeft het wetgevend gezag der Kroon sinds 1851 de instelling der Kamers van Koophandel absoluut laten liggen, dat is gedurende meer dan een halve eeuw.

De Wetgevende Macht heeft verzuimd, nu en dan nieuwen inhoud te geven aan den werkkring der Kamers.

De Departementen van Algemeen Bestuur hebben een onpractisch stelsel gevolgd bij het inwinnen van de adriezen der Kamers over andere dan lokale belangen; en door den omslag; die te vermijden ware geweest, het heginsel zelf is een kwaden roep geplaatst.

De geldmiddelen der Kamers zijn onvoldoende, behalve te Amsterdam en te Rotterdam. Te Tilburg besteedt de Kamer ruim f 300 's jaars; de gezamenlijke Kamers van Twenthe beschikken over ongeveer duizend gulden per jaar. Uit zulke nietige cijfers alleen reeds kan men wel vermoeden, dat de industrieelen hun belangen niet via cle Kamers plegen te behartigen! Ook dit voorbijgaan van de Kamers heeft hun aanzien geschaad.

De Kamers geraakten, in één woord, in het moeras; en er was niemand om ze daaruit te bevrijden.

De voor de hand liggende maatregelen zijn deze. Een ruimer budget. Verbreking van den band met den Gemeenteraad. Vertrouwen geven.

Verbreking van den band met den Gemeenteraad brenyt eenige wijziging in het kiesrecht mede. Het aantal kiezers is onder vigeur van de regeling van 1896 tot een belachelijk gering aantal verminderd.

De Kamers zullen zich, indien de nieuwe regeling het aantal leden tijdelijk uitbreidt, wat de samenstelling betreft, kunnen vernieuwen. Met ruimer geldmiddelen zullen zij zich van andere hulp kunnen en moeten voorzien dan verwacht kan worden van die tegenwoordige secretarissen, veelal secretarie-beambten wier opleiding 
voor gemeente-ambtenaar hen de noodige kennis niet gegeven heeft voor dit ambt.

Geleidelijk, 't is waar, maar van stonde aan kan de hervorming beginnen.

Bovendien geve de Wetgevende Macht de Kamers geleidelijk nieuw werk.

Komt het Handelsregister tot stand, de uitvoering zout in hunne handen gelegd kunnen worden, omdat zij met Staatsgezag omkleed zijn.

Ongelooflijk maar waar is het, dat tegenwoordig de "Jaarcijfers" geen enkel gegeven uit de jaarlijksche verslagen der Kamers van Koophandel ontleenen. Welnu, deze publicatie putte meer dan tot dusverre eenige gegevens omtrent handiel en industrie uit die verslagen, waarvan sommige met groote bekwaamheid samengeste!d zijn.

In de Centrale Commissie voor de Statistiek komt de invoering van een algemeene productie-statistiek aan de orde. Zou de tusschenkomst van de bureaux der Kamers ook ingeroepen kunnen worden. Het lijkt mogelijk, indien deze statistiek zich aanvankelijk tot een deel van het terrein beperkt. Toone nu de overheid, door hun tusscherikomst te vragen, dat zij b!j die lichamen wezenlijke belangstelling in de publieke zaak aanwezig acht. Eien statistisch onderzoek kan door bekendheid van de enqueteurs met personen en toestanden veel winnen aln nauw. keurigheid. Laten de Kamers deze gelegenheid verlirijgen, om werkzaam aandeel te nemen in een nieuwe bemoeiïng der overheid. Ook dit $z$ a 1 de colleges rehabiliteeren in de publieke opinie.

De mismoedige stemming, de klachten over miskenning, liggen niet in het adviseerend karakter op zichzelf, maar in de verwaarloozing van dat beginsel.

In zuiver lokale belangen behoorde het in den wind slaan van de adviezeti der Kamers niet voor te komen.

Toen in den eersten crisistijd herhaaldlelijk ianviagen van particulieren de Kamers bereikten ${ }^{1}$ ), die, door den oorlog hun gewone leveranciers verloren hebbend, cen anderen zochten, vond een Kamer het nuttig, ten behoeve van de publicatie van dergelijke ongewone behoeften, te beschikken over eenige aanplakruimre in de hal van het postkantoor. Het werd door het Hoofdbestuur der Posterijen en Telegrafie geweigerd ,omdat het postkantoor alleen bestemd is voor mededeelingen van de Departementen van Algemeen Bestuur." Dit nu is betweterii, die voor het initiatief van een Kamer fnuikend

1) Dit is een persoonlijke herinnering aan de Kamer te Hilversum. 
is. 1) De centrale overheid volge in dergelijke zaken onvoorwaardelijk het advies, inplaats van met minachting het te bejegenen.

De postadministratie is onbekend met de uit de gedwongen 9-uur-winkelsluiting voortvloeiende wijeigingen in de plaatselijke toestanden; althans wordt wel overgegaan tot wederinstelling van sinds de mobilisatie opgeheven late bestellingen, waarvan het nut miniem is geworden, en die de meerdere kosten volstrekt niet motiveeren. Ook dit ondervond de Kamer waar ik werl:zaam was. Het Hoofdbestuur reageerde op krantengeschrijf, en verzuimde, de Kamer om advies te vragen. Het kost de schatkist drie duizend gulden per jaar.

Die nonchclante beiegening van de Kamers nu eens, het passeeren bij een andere gelegenheid, ofschoon de Kamer volkomen competent is, dat alles geschiedt tot schade van het algemeen belang!

Vandaar mijne warme belangstelling.

Feitelijk zijn thans vooral de Kamers te Amsterdam en te Rotterdiam in het bezit van populariteit. Verscheidene van de overige zijn tot machteloosheid veroordeeld door gekortwiekte geldmiddelen en door de aangewreven reputatie van ,,praatcolleges", een reputatie die verdiwijnen moet, en die het spoedigst verdwijmen zal, indien door de Regeering en door de Wetgevende Macht een ander wachtwoord gegeven wordt.

Mogen deze eenvoudige mededeelingen uit de practijk iets er toe bijdragen, om de Kamers - met behoud van het publiekrechtelijk karakter dezer instelling - tot veel vruchtdragenden arbeid in staat te doen stellen.

Hoek van Holland, Maart 1917.

W. Elink Schu ur man.

1) Voor het nemen van deze beslissing had het Hoofdbestuur a cht maanden tijds noodig!! 